This document was prepared in conjunction with work accomplished under Contract No. DE-AC09-96SR18500 with the U. S. Department of Energy.

\title{
DISCLAIMER
}

This report was prepared as an account of work sponsored by an agency of the United States Government. Neither the United States Government nor any agency thereof, nor any of their employees, nor any of their contractors, subcontractors or their employees, makes any warranty, express or implied, or assumes any legal liability or responsibility for the accuracy, completeness, or any third party's use or the results of such use of any information, apparatus, product, or process disclosed, or represents that its use would not infringe privately owned rights. Reference herein to any specific commercial product, process, or service by trade name, trademark, manufacturer, or otherwise, does not necessarily constitute or imply its endorsement, recommendation, or favoring by the United States Government or any agency thereof or its contractors or subcontractors. The views and opinions of authors expressed herein do not necessarily state or reflect those of the United States Government or any agency thereof. 


\section{Biological Treatment of Petroleum in Radiologically Contaminated Soil}

by

CHRISTOPHER BERRY

Westinghouse Savannah River Company

Savannah River Site

Aiken, South Carolina 29808

Additional Authors:

ROBIN BRIGMON

This paper was prepared in connection with work done under the above contract number with the U. S. Department of Energy. By acceptance of this paper, the publisher and/or recipient acknowledges the U. S. Government's right to retain a nonexclusive, royalty-free license in and to any copyright covering this paper, along with the right to reproduce and to authorize others to reproduce all or part of the copyrighted paper. 


\title{
Biological Treatment of Petroleum in
}

\section{Radiologically Contaminated Soil}

\author{
C. J. Berry, ${ }^{1,2}$ S. Story, D. J. Altman, ${ }^{2}$ R. Upchurch, ${ }^{3}$ W. Whitman, ${ }^{3}$ \\ D. Singleton, G. Plaza, ${ }^{4}$ and R. L. Brigmon ${ }^{1,2}$ \\ ${ }^{1}$ Savannah River National Laboratory, Aiken SC 29808 \\ ${ }^{2}$ Westinghouse Savannah River Company, Aiken, SC 29808 \\ ${ }^{3}$ Departments of Microbiology and Ecology, University of Georgia, Athens, \\ GA 30602 \\ ${ }^{4}$ Institute for Ecology of Industrial Areas, Katowice, Poland
}

This chapter describes ex situ bioremediation of the petroleum portion of radiologically co-contaminated soils using microorganisms isolated from a waste site and innovative bioreactor technology. Microorganisms first isolated and screened in the laboratory for bioremediation of petroleum were eventually used to treat soils in a bioreactor. The bioreactor treated soils contaminated with over $20,000 \mathrm{mg} / \mathrm{kg}$ total petroleum hydrocarbon and reduced the levels to less than $100 \mathrm{mg} / \mathrm{kg}$ in 22 months. After treatment, the soils were permanently disposed as low-level radiological waste. The petroleum and radiologically contaminated soil (PRCS) bioreactor operated using bioventing to control the supply of oxygen (air) to the soil being treated. The system treated 3.67 tons of PCRS amended with weathered compost, ammonium

nitrate, fertilizer, and water. In addition, a consortium of microbes (patent pending) isolated at the Savannah River

RESERVE THIS SPACE 
National Laboratory from a petroleum-contaminated site was added to the PRCS system. During operation, degradation of petroleum waste was accounted for through monitoring of carbon dioxide levels in the system effluent. The project demonstrated that co-contaminated soils could be successfully treated through bioventing and bioaugmentation to remove petroleum contamination to levels below $100 \mathrm{mg} / \mathrm{kg}$ while protecting workers and the environment from radiological contamination.

\section{Introduction}

The Savannah River Site (SRS), a Department of Energy (DOE) facility located in South Carolina, has generated non-hazardous petroleum and radiologically contaminated soils from spills and past disposal practices (1). The South Carolina Department of Health and Environmental Control (SCDHEC) regulations allow for burial of petroleum-contaminated soils in sanitary landfills with total petroleum hydrocarbon (TPH) concentrations below $100 \mathrm{mg} / \mathrm{kg}$, but no allowances are made for disposal of radiologically and petroleum cocontaminated soil (2). Therefore, these co-contaminated soils were being stored in low-activity vaults for an indefinite period of time. SRS submitted a corrective action plan to SCDHEC that proposed ex situ cleanup of the petroleum portion of the soils using simple, inexpensive, and safe bioreactor technology (3). Final disposal of the treated soil, after treatment of the petroleum contamination, was burial in SRS trenches that accept low-level radiological wastes (4). The petroleum and radiologically contaminated soil (PRCS) bioreactor was developed to provide and demonstrate an efficient treatment pathway for this material to reduce operating costs, to provide a safe remedial method for treatment of spills, and to be applicable to other cocontaminated soils. Here, we describe how bacteria were isolated, screened and tested at the laboratory scale and applied to remediate tons of petroleumcontaminated soil in the PRCS bioreactor.

\section{Biotreatment Technology}

Biostimulation and/or bioaugmentation are effective alternatives to traditional physicochemical techniques for the cleanup of petroleumcontaminated soils (5). Current physicochemical techniques for disposal or decontamination of hydrocarbon-contaminated soils include landfill disposal, incineration, vapor extraction, detergent washing, and chemical oxidation (6). 
Biodegradation of petroleum hydrocarbons by stimulation of indigenous soil microorganisms, also known as biostimulation, is a proven remediation technology. Biostimulation involves the addition of electron acceptors, electron donors or nutrients to enhance the activity of indigenous microorganisms (7). Bioaugmentation involves the addition of indigenous or non-indigenous laboratory-grown microorganisms capable of biodegrading target contaminants $(7,8)$ or serving as donors of catabolic genes (9). Bioremediation of hydrocarbon-contaminated soils, which uses the natural ability of microorganisms to degrade and/or detoxify organic compounds, has been established as an efficient, economic, versatile, and environmentally sound treatment.

\section{Impact of Radioactivity on Microorganisms}

The impact of high levels of radiation on microbial activity and survival has been studied, but the impact of low-level waste on microbial survival and activity has not (10). Microbial survival studies have reported that Bacillus spores and Kineococcus radiotolerans have withstood radiation up to $3.5 \mathrm{kGy}$, and a ten percent survival of Escherichia coli was reported after a dose of 500 Gy (11). Deinococcus radiodurans (12) has survived a chronic dose of $20 \mathrm{kGy}$ and an acute dose of $10 \mathrm{kGy}$. The lethal dose, or dose that would be expected to cause immediate incapacitation and death of a human within one week, is approximately 50 Gy (13). In general, bacteria are much more resistant to radiation fields than humans. Although strict dose rate levels are not used to define low-level radioactive waste, the petroleum-contaminated soils stored in the low-level vaults at the SRS do not generate doses greater than $100 \mu \mathrm{Gy}$ per year. Smith et al. (14) used risk-based modeling to assess the impact of disposal of radioactive petroleum waste in nonhazardous landfills and found that disposal of technologically enhanced, naturally occurring radiological materials presented a negligible risk to most potential receptors evaluated in their study. Since low-level waste storage is characterized based on risks to humans, any impact on microorganisms should be minimal.

\section{Soil Treatment and Bioventing}

Bioventing refers to enhanced bioremediation through the active or passive addition of oxygen (15). Enhanced bioremediation using bioventing to treat petroleum-contaminated soils requires an understanding of the basic principles of system design and microbial processes. When possible, contaminated soil is more efficiently treated if the biological treatment can be performed ex situ (16), 
since the addition of necessary nutrients, bulking agents, bacteria, and oxygen can be applied more easily than in situ. Biostimulation, or the addition of nutrients, can be applied both above ground in prepared beds or reactors and below ground using bioventing. Bioventing uses air injection or vacuum extraction to increase oxygen levels and is appropriate for relatively porous soil (17). However, contrary to soil vapor vacuum extraction, flow rates are relatively low to prevent stripping, but high enough to enhance microbial metabolism (18). Bioventing has been used to remediate gasoline-, diesel-, and PAH-contaminated soils (19).

\section{Bioventing Requirements}

If adequate amounts of oxygen, moisture and nutrients are available and the contaminants are accessible to the microorganisms, complete degradation of petroleum hydrocarbons can occur. Aerobic conditions and appropriate microorganisms are necessary for an optimal rate of bioremediation of soils contaminated with petroleum hydrocarbons (17). The oxygen content of soils depends on microbial activity, soil texture, water content, and depth. Low oxygen content/availability in soils has been shown to limit bioremediation of petroleum hydrocarbons (20). In a laboratory column experiment with acclimated soils, mineralization of hydrocarbons was severely limited when the oxygen content was below $10 \%(21)$.

Moisture levels are important for microbial enzymatic activity and proper operation of bioventing processes (22). In general, enzymatic reaction rates increase with increased moisture, although enzymatic reactions have been shown to decrease when specific metal ions were mobilized as a result of increased soil moisture (23). However, in a bioventing system, the presence of saturated soils limits airflow, permeability, or conductivity through the soil bed and impacts oxygen distribution. Soil moisture levels between 25\% and $85 \%$ have been reported as suitable for bioremediation (24).

Microbial processes require nutrients for cellular processes, growth, and reproduction. Oxygen acts as an electron acceptor for aerobic bacteria and is required for cellular processes to occur. Nitrogen has been successfully introduced into the terrestrial subsurface for biostimulation using ammonia, nitrate, urea, and nitrous oxide (25). Several inorganic and organic forms of phosphate have been successfully used to biostimulate contaminated environments (25). In general, the addition of inorganic fertilizers in a ratio ranging from 9 to 600 to 1 , carbon to nitrogen, potassium, and phosphorus has been reported to stimulate remediation of petroleum-contaminated soils (6). Complex organic sources of nutrients, e.g., compost, have also been shown to 
increase microbial activity (26) and diversity that can enhance bioremediation of organic contaminants (27).

\section{Bioavailability of Contaminants}

The bioavailability of contaminants is an important factor in bioremediation. The bioavailability of a chemical may be described by its mass transfer rate relative to its uptake and degradation rates by microorganisms (28). If the capacity for hydrocarbon degradation is present and environmental conditions are amenable, the microorganisms must have access to the contaminants for degradation (29). Reduced bioavailability could be caused by low aqueous solubility and strong sorption to soils or sediments (30). It has been shown that the water-dissolved fraction of chemicals is more available to soil microorganisms (31). The use of surfactants has been shown to increase biodegradation of hydrocarbon contaminants by increasing bioavailability (32). Temperature is an important parameter for most bioremediation sites because of its impact on the availability of contaminants and the activity of the microorganisms. Especially true in northern latitudes, seasonal variation can also impact bioremediation sites (33). For optimal contaminant removal, biological treatment of organic pollutants such as petroleum-based hydrocarbons is performed at moderate temperatures $\left(20^{\circ}\right.$ to $\left.37^{\circ} \mathrm{C}\right)$ in order to increase metabolic activity, diffusion, and mass transfer.

Modifying soil composition and structure through mechanical means or amendments can significantly influence bioremediation activities. Bulking agents are materials of low density that lower soil bulk density, increase porosity, moisture retention and oxygen diffusion, and can help to form waterstable aggregates increasing aeration and microbial activity (34). Indigenous microbes, those growing naturally in soil, sediment, or groundwater, and nonindigenous microbes, those added from an external source, have been used in bioremediation of petroleum hydrocarbons (35). However, refining of petrochemicals results in the generation of oil sludge consisting of hydrophobic compounds resistant to biodegradation (36). The addition of surfactantproducing non-indigenous microbes or synthetic surfactants has been used in soil treatment to help increase availability of these recalcitrant materials (37). Moreover, the production and presence of biosurfactants has been shown to have many of the benefits of synthetic surfactants as well as being biodegradable and nontoxic (38). Although non-indigenous organisms must be able to compete for nutrients and retain their ability to degrade contaminants, bioaugmentation has been shown to work in field conditions for a variety of organic compounds (39). 


\section{Methods}

\section{Microbial Isolation and Characterization}

A consortium of microbes isolated at the Savannah River National Laboratory (SRNL) from a petroleum-contaminated site was added to the PRCS system. The organisms were isolated from sludge samples obtained from a 100year-old oil refinery near Czechowice-Dziedzice, Poland (40). The aged sludge was acidic ( $\mathrm{pH} 2$ ) and composed of asphaltics that were highly contaminated with polycyclic aromatic hydrocarbons (PAHs) (41).

One gram samples (wet weight) of sludge or biopile material were suspended in $10 \mathrm{ml}$ of $0.1 \%(\mathrm{w} / \mathrm{v})$ sodium pyrophosphate buffer $(\mathrm{pH} \mathrm{7})$ and vortexed. Serial dilutions were on plates with minimal agar $(\mathrm{pH} 4)$ exposed to naphthalene vapor for two weeks. Bacterial colonies with distinct morphotypes were picked and transferred to the same agar medium for purification and subsequent characterizations. The number of potential phenanthrene degraders was determined by spraying a saturated solution of phenanthrene in hexane directly to the colonies on the agar surface. After an additional week of incubation, colonies that removed the phenanthrene crystals around their periphery were selected and characterized further. Microorganism were then identified as previously described (41).

The biosurfactant exudate was evaluated for each isolate and those determined to have a surface tension-altering property consistent with a surfactant were retested. In preparation for addition to the bioreactor, microbial isolates were grown in peptone, tryptone, yeast, and glucose (PTYG) medium. The PTYG media consisted of $1 \mathrm{~g} / \mathrm{L}$ of peptone, $1 \mathrm{~g} / \mathrm{L}$ of tryptone, $2 \mathrm{~g} / \mathrm{L}$ of yeast, $1 \mathrm{~g} / \mathrm{L}$ of glucose, $0.45 \mathrm{~g} / \mathrm{L}$ of $\mathrm{MgSO}_{4}$, and $0.07 \mathrm{~g}$ of $\mathrm{CaCl}_{2}$ (all reagents from Fisher Scientific or Difco-Becton, Dickenson and Company, Franklin Lakes, NJ). Isolates were grown at $28^{\circ} \mathrm{C}$ on a shaker flask until bacterial densities were greater than $1 \times 10^{7}$ cell $/ \mathrm{ml}$. Active cultures were in log phase growth when 2 liters were prepared for direct addition to the PCRS bioreactor.

\section{Reactor Construction}

The bioreactor was constructed from a $6.75 \mathrm{yd}^{3}$ volume skid-pan by adding a false floor, sample ports, lid with seals, gauge ports, HEPA filters, and air pumps (10). 


\section{Bioreactor Soil Sampling}

Soil sampling required protection from radioactive contamination. This included wearing multiple sets of gloves, using hand-held radiological monitoring equipment, and swipes for alpha contamination (Eberline AC-3, Thermo Electron Corporation, San Jose, CA), beta/gamma contamination (Ludlum model 12 with an HP 110 probe), and radiation (RO-20, Thermo Electron Corporation). Before sampling, all system pumps were turned off and all relief valves were opened. Once the pressure/vacuum gauges on the PRCS bioreactor read "zero" the access port was opened. Soil samples were taken by hand using a three-foot carbon steel sampling rod with a stainless steel sampling probe. Multiple 50 gram soil samples were taken from randomly selected holes to screen the entire vertical soil profile of the PRCS system. The soil from each hole was immediately placed in a sterile, $50 \mathrm{ml}$ polypropylene centrifuge tube (Corning, Acton, MA). Once sampling was complete, the samples were packed on ice and transported in to an SRS radiological facility located in the SRNL. Collected soils were stored at room temperature, and analyses were performed within 7 days of sampling.

\section{Measurements}

Hydrocarbon concentrations were performed using a gravimetric method, and analyses were performed using gas chromatography in conjunction with a mass selective detector (10). Soil nutrient levels, $\mathrm{pH}$, and soil moisture were monitored by quantitating the water-soluble inorganic forms of nitrate, nitrite, ammonia, potassium, and phosphate (10). Gas samples were taken from a sampling valve downstream of the effluent line HEPA filter were analyzed in a non-radiological laboratory (10) for carbon dioxide, oxygen and hydrocarbons. Carbon dioxide generation rates were determined on weathered compost as previously described (10) using less weathered but similar material from the same source. Temperature, vacuum, and air flow rates were taken from the unit (10).

\section{Reactor Loading}

Two radiological material storage boxes (B-12 boxes) containing 7,340 lb of petroleum and radioactive contaminated soil were loaded onto the grating inside the bioreactor. A Typar ${ }^{\circledR}$-style (Tri-State Stone ${ }^{\circledR} \&$ B Building Supply, Inc., Bethesda, MD) geotextile fabric was placed on top of the grating inside the bioreactor. While loading, the soil was amended by mixing in $6 \mathrm{ft}^{3}$ of compost, 
1.36 pounds of ammonium nitrate (Fisher Scientific) and 0.54 pounds of 10-1010 fertilizer (Lowe's ${ }^{\circledR}$, Aiken, SC). Bags of mixed compost and fertilizer were manually added to the reactor system toward the end of each B-12 transfer. Once the bioreactor was filled, the soil inside the reactor was leveled using a hoe. When level, the soil covered the lower two rows of temperature and pressure gauges. The upper third row of gauges, vacuum relief valve, and pressure relief valve were not in contact with the soil. After leveling, an estimated total of 80 gallons of water was added to the system. The initial contamination level in the system, fully loaded, was estimated to be 25,000 $\mathrm{mg} / \mathrm{kg} \mathrm{TPH}$, based on analyses of the loaded soil.

\section{Operation of the Reactor}

The PRCS bioreactor operated for 22 months in various configurations treating the contaminated soil. Initial soil TPH concentration was greater than $25,000 \mathrm{mg} / \mathrm{kg}$, and the final TPH concentration was $45 \mathrm{mg} / \mathrm{kg}$. Ten days after loading and staging the PRCS system, the system began continuous operation. System parameters were initially adjusted so that there was a slight vacuum, less than 0.6 inch water, on all of the pressure gauges. The system operated in a variety of configurations and two different locations during testing. The following operating ranges were used as guidance for operation of the bioreactor: oxygen concentration, $10-21 \%$ in air; soil moisture, $8-20 \%$ by weight; carbon:nitrogen:phosphorus ratio, 100:10:2 or greater for nitrogen and phosphorus; soil $\mathrm{pH}, 4-7$; and soil temperature, $15-35^{\circ} \mathrm{C}$.

The system operated continuously, except for down times due to sampling, during the first four months of operation. During month five, 58 gallons of tap water, open to the atmosphere for 5 days, were pumped into the system to adjust soil moisture levels, and three soil samples were pulled from the reactor. During the sixth month of operation, temperature and carbon dioxide production levels were low, and the inlet and outlet air pumps were turned off. The system was checked biweekly to operate the pumps and check carbon dioxide levels. In months eight to eleven, the pumps were operated periodically to purge carbon dioxide from the system and provide oxygen. During the tenth month of operation, the system was moved from a covered facility with power to an outside radiological storage area. A cover was constructed to provide protection from the sun and rain, and the system was operated using a portable generator.

During month twelve, the inlet pumps were replaced with larger flow pumps to facilitate increased aeration and carbon dioxide removal. Carbon dioxide removal was achieved by operating the system for approximately 90 min on a weekly basis. In the thirteenth month of operation, a solar-powered pump system was installed. During month nineteen a soil sample was taken for 
analyses by General Engineering Laboratories (Charleston, SC). Analyses of PRCS soil showed TPH concentrations of $279 \mathrm{mg} / \mathrm{kg}$. This was above the 100 $\mathrm{mg} / \mathrm{kg}$ required by SCDHEC for disposal. Carbon dioxide was not measured exiting the system in month twenty-two. The system soil was sampled in month twenty-two for external analyses. Results were obtained in month twenty-two and confirmed successful treatment of the soil to less than $100 \mathrm{mg} / \mathrm{kg}$. The soil was then disposed in a lined slit trench located on the low-level radiological burial ground, E-Area, at SRS.

\section{Soil Analyses}

Soil samples were taken from one of the B-12 boxes prior to loading the system and from the PRCS five times during operation. Samples were taken at three weeks, four months, fourteen months, nineteen months, and twenty-one months. Soil hydrocarbon concentrations were measured for all of the sampling events. Soil moisture levels were measured at months four and fourteen, and soil $\mathrm{pH}$ was measured on the B-12 box during week three. Soil nutrient levels were obtained from the B-12 box prior to loading the system, at three weeks and fourteen months.

\section{Results and Discussion}

Twelve of the bacterial isolates were shown to have consistent activity for bioremediation of petroleum compounds. Nine of these organisms added for bioaugmentation are listed in Table 1. Isolates 1-3, Alcaligenes piechaudii SRS, Ralstonia pickettii SRS, and Pseudomonas-putida Biotype B SRS, all demonstrate the ability to produce biosurfactants in the presence of petroleum compounds, the formation of which was noted during culturing conditions (Table 1). Isolates 4-9 all demonstrate the ability to biodegrade a variety of petroleum hydrocarbons (Table 1).

\section{System Monitoring}

Soil moisture analysis was performed on samples pulled during months four and fourteen. In month four, the average soil moisture level from 5 samples was $10.6 \%$, which was close to the lower operating limit of $8 \%$. Additional water was added to the system. In month fourteen the average soil moisture levels from 3 samples was $12.4 \%$. Soil moisture levels were indirectly monitored by measuring the level of water in the bottom of the PRCS system using a stud 
Table 1. Bacteria Cultures Used for Bioaugmentation

\begin{tabular}{cll}
\hline Number & \multicolumn{1}{c}{ Isolate } & \multicolumn{1}{c}{ Identification } \\
\hline 1 & CZOR-L1B (KN-1) & Alcaligenes-piechaudii SRS \\
2 & BP-20 (KN-2) & Ralstonia pickettii SRS. \\
3 & CZOR-L1Bsm (KN-3) & Pseudomonas putida Biotype B SRS \\
4 & BPB & Flexibacter cf. sancti SRS \\
5 & BPC & Pseudomonas fredriksbergensis SRS \\
6 & BPE & Staphylococcus warneri. LMG 19417 SRS \\
7 & BPF & Sphingomonas SRS \\
8 & BPH & Sphingomonas Sp. S37 SRS \\
9 & BPI & Phylobacterium SRS \\
10 & CZOR-L1B (KN-1) & Alcaligenes piechaudii SRS - $(\alpha$ \\
& & Proteobacterium TA-A1) \\
\hline
\end{tabular}

finder. Greater than one inch of water was detected in the bottom of the reactor until month nineteen.

Soil $\mathrm{pH}$ levels were measured in soils pulled from the B-12 box prior to system startup and at three weeks into operation. Soil pH was 5.9 in the B-12 box sample initially and 6.2 during week three. Soil nutrients that were measured using ion chromatography included nitrate, nitrite, ammonia, phosphate, and potassium. Analyses were performed on the B-12 box prior to loading and on the three-week soil samples. Although total nitrogen was not determined due to the high levels of ammonium present, available nitrogen, potassium and phosphate concentrations were present.

Due to the heterogeneity of the samples taken in the third week, all sampled material was combined, mixed by hand, and separated into four samples. The samples analyzed by the outside laboratories were analyzed once. Results from month four and fourteen are averages of duplicate samples. Results for the SRNL analyses of the B-12 box, four month and fourteen month samples are from gravimetric analyses.

General Engineering Laboratories also analyzed soil samples for benzene toluene ethyl benzene and xylenes (BTEX) using SW-846 8260B; PAHs using SW-846 8270; and GRO using SW-846 8015B (42). No detectable BTEX, $\mathrm{PAH}$ or gasoline range organics were measured. Final analyses by Accura Analytical, (Norcross, GA) demonstrated TPH, as measured by diesel range 
organic analysis, was $45 \mathrm{mg} / \mathrm{kg}$, which was less than the $100 \mathrm{mg} / \mathrm{kg}$ maximum disposal level required by SCDHEC at month twenty-two.

Flow rates entering and exiting the system were primarily determined by the pump type being used. Three sets of pumps were used to operate the system. Flow rates using the medium-sized pumps ranged from 30 to over 75 SCFH with an average flow rate of $48 \mathrm{SCFH}$. Inlet and outlet flow rates using the larger pumps averaged $225 \mathrm{SCFH}$. Inlet and outlet flow rates using the solar-powered pumps ranged from 10 to $20 \mathrm{SCFH}$ with an average flow rate of 17.5 SCFH.

PRCS bioreactor temperatures were taken at three points, one in the headspace of the system and two in the soil profile of the unit. Maximum soil temperatures, above $25^{\circ} \mathrm{C}$, were measured during the first four months of operation and during months eleven through fifteen. Minimum temperatures, below $15^{\circ} \mathrm{C}$, were measured at the end of the fifth month of operation through the ninth month and in months seventeen through twenty-one. Soil temperatures changed with the median outdoor temperature as the cell was sheltered from rain. Methane was not detected in any sampling of the system using the portable analyzer or in any gas bag samples. VOCs also were not detected in any gas bag samples. Oxygen concentrations were measured during the first three months of operation averaging value was $17.12 \%$.

Carbon dioxide measurements were used to monitor hydrocarbon degradation, microbial activity, and to indicate when the system had completed bioremediation of the contaminated soil (Figure 1). Carbon dioxide concentrations exiting the system were used with system flow parameters, the mass of contaminated soil, and the stoichiometric ratio of an alkane, $>\mathrm{C} 11$, to carbon dioxide in a hydrocarbon oxidation reaction to calculate theoretical hydrocarbon degradation rates.

The major physical impacts on reactor performance were soil temperature and pump operation. Soil temperatures changed with ambient temperature changes (probability $>t<0.0001$ ). TPH degradation and soil temperature also were also somewhat related (probability $>\mathrm{t}<0.0001$ ) (Figure 1). During the first decrease in temperature, days 123-250, carbon dioxide production dropped below $10 \mathrm{mg} / \mathrm{kg} / \mathrm{day}$. Carbon dioxide production also indicated a general decrease in degradation rate during the second temperature decrease, days 500600 , although overall degradation rates were higher during the second temperature decrease.

Carbon dioxide production was also reduced during day 175 through day 400 when pump operation was intermittent (Figure 1). Low TPH degradation was observed while soil temperatures were relatively high, above $15^{\circ} \mathrm{C}$, but flow rate through the system was low. When continuous flow was returned to the system using the solar pumps, TPH degradation increased to over $50 \mathrm{mg} / \mathrm{kg} /$ day, but then decreased throughout the remainder of system operation. Overall, 
pump operation was related to TPH degradation (probability $>t=0.4$ ), as shown in Figure 1.

Using a portable generator reduced the amount of oxygen (air) that was added to the PRCS system and impacted TPH degradation rates compared to continuous operation with permanent power or with solar pumps (Figure 1). During operation in the field using a portable generator, the bioreactor operated an average of once a week. The system was designed to vent to the atmosphere through the HEPA filters. Therefore, the volume expansion resulting from temperature increases or net gas/vapor production would cause gaseous material to be vented from the system and would change the headspace volume used to

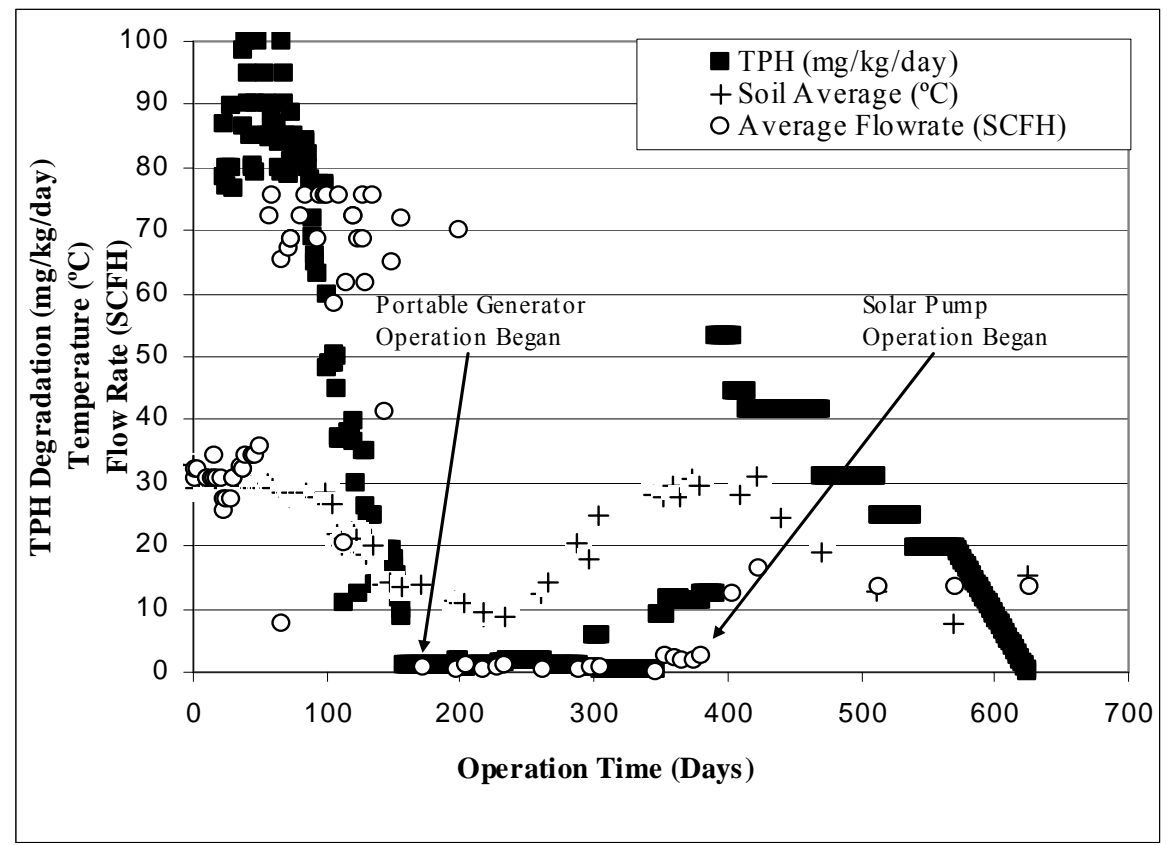

Figure 1. Bioreactor degradation, air flow, and temperature.

to calculate TPH degradation.

In general, using carbon dioxide concentrations to monitor TPH degradation has uncertainties, but is an effective parameter to use for external measurements. Using the mass ratio between an alkane and carbon dioxide in the hydrocarbon oxidation reaction yields the following relationship: 


$$
-\mathrm{r}_{\mathrm{TPH}} \approx 0.31 \frac{\mathrm{mgTPH}}{\mathrm{mgCO}_{2}} \mathrm{r}_{\mathrm{CO} 2}
$$

where $-r_{\mathrm{TPH}}$ is the rate of hydrocarbon degradation and $\mathrm{r}_{\mathrm{CO} 2}$ is the carbon dioxide production rate. TPH degradation is underestimated when aromatics, PAHs, and olefins are being degraded, but it is relatively accurate for branched alkanes. The typical hydrocarbon content of gasolines is $25-40 \%$ isoalkanes, and $20-50 \%$ aromatics (43). Huesemann (44) showed the general rate of biodegradation of petroleum compounds was in the order of $n$-alkanes $>$ branched-chain alkanes $>$ branched alkenes $>$ low-molecular-weight $n$-alkyl aromatics $>$ monoaromatics $>$ cyclic alkanes $>$ polynuclear aromatics $>$ asphaltenes. Equation (1) would accurately estimate TPH degradation during early biodegradation but would overestimate degradation rates as treatment continued. Factors ignored in Equation (1) include the impact of the soil organic content, amendments added to the system, and the volatilization of breakdown products besides carbon dioxide. SRS soils are generally sandy with low organic carbon content so the impact of background organic carbon contributing to carbon dioxide generation should be minimal. Composted materials were also added to the bioreactor and contributed to carbon dioxide production but were neglected based on low production rates (10). Using carbon dioxide to monitor system operation was useful especially since internal system sampling was limited due to radiological protection issues. Although TPH degradation rate estimates are impacted by many factors, monitoring carbon dioxide production provided a straightforward monitoring tool during operation of the PRCS bioreactor.

Examination of GC/MS sample runs on untreated and treated soil showed that most of the petroleum contamination consisted of an unresolved complex mixture of hydrocarbons. This mixture has been described as resulting from the chromatographic overlap of thousands of compounds (45). Analyses of the total ion chromatograph did not reveal the presence of distinct chemical compounds but did show a mixture of co-eluting compounds with column residence times falling after the internal standard, deuterium-labeled anthracene. The total ion chromatogram was examined for general trends and specific PAH masses. Generally, mass per charge responses increased by 14 units in the unrefined area, indicating an additional carbon group (46). Major masses consistent with PAHs were not identified, and NIST library searches, with a probability greater than 50 , did not identify any specific compounds. The extended storage period for this material before processing probably contributed to the small number of compounds that were identified using GC/MS analyses. Easily degradable and identifiable compounds were preferentially degraded first (44), probably during storage. 
Degradation of this complex mixture of compounds required microorganisms with specialized enzymatic activities. The phenomenon has been described (35), and degradation of this complex mixture of compounds is slower than degradation of alkanes. The organisms that were inoculated into the PRCS system were isolated from a refinery site containing asphaltenes and other complex materials. Enzyme systems that were present in microorganisms in this refinery site waste could use these more complex compounds for growth. Although specific organisms and specific enzyme activity were not tracked in this investigation due to the radioactive nature of the waste, a change in the active microbes during PRCS operation is probable. The addition of select isolates that produce biosurfactants is believed to have enhanced remediation through several different mechanisms. The production of the biosurfactant increases the biological availability of PAHs and other hydrophobic petroleum compounds. As such, the natural ability to produce surfactants increases the efficiency of the microorganisms to degrade and metabolize PAHs in the weathered, petroleum-contaminated soils.

Using bioventing to treat petroleum-contaminated soil is a well-documented approach (47), but using bioventing to treat radiologically and petroleum cocontaminated soils has not been reported. During this testing it was demonstrated with proper engineering controls for worker and environmental protection, co-contaminated soils can be safely biovented. Bioventing in this bioreactor was designed to maximize the biodegradation of petroleum contaminants with little volatilization. Most of the common soil environmental radioactive contaminants (i.e., cesium, plutonium, and uranium) found at SRS have low volatility so release of radioactive material out of the system would not be expected. To ensure this did not occur, HEPA filters were placed on all process entry and exit points to trap any particulates, and the system was operated under a slight vacuum to protect the environment. Finally, the system was shut down, monitored, and protective clothing was worn when the bioreactor was opened. Based on the biodegradation rates and complete treatment in the PRCS bioreactor, the impact of the radiological contamination on the treatment was minimal.

\section{Conclusions}

Based on the results of this study the following conclusions are offered. A biovented bioreactor system can be used to effectively treat future cocontaminated soils at SRS and other locations. Carbon dioxide measurements were shown to be a good indicator and monitoring tool for microbial activity and TPH degradation. Soil temperature and the oxygen supply were identified as two important parameters that control the rate of biodegradation. Complete 
treatment time required twenty-two months of operation and reduced TPH levels from over $20,000 \mathrm{mg} / \mathrm{kg}$ to $45 \mathrm{mg} / \mathrm{kg}$. Soil was permanently disposed of in low-level Rad waste trenches resulting in a significant reduction in disposal costs. Both carbon dioxide and hydrocarbon should be monitored in situ to determine the extent and rate of TPH degradation. The use of heating strips or the addition of insulation should be considered when treating soil in temperate climates. Biological treatment of co-contaminated soil was successfully completed using an ex situ bioreactor system safely.

\section{References}

1. Lombard, K.; Hazen, T.C. Test Plan for the Soils Facility Demonstration A Petroleum Contaminated Soil Bioremediation Facility; WSRC-RP-940179; DOE: Savannah River Site; 1994.

2. SCDHEC. South Carolina Hazardous Waste Management Act; \#61-107.18; 2001.

3. Kastner, J.R.; D. J. Altman; C. B Walker. Corrective Action Plan Degradation of Petroleum Contaminated Soils Using Ex-Situ Bioreactors and Bioventing, WSRC-RP-97-25; Savannah River Site; 1998.

4. Mamatey, A.E., (ed.). Savannah River Site Environmental Report for 2003, WSRC-TR-2004-00015; DOE: Savannah River Site; 2003.

5. Dua, M.; Singh, A.; Sethunathan, N.; Johri, A.K. Appl. Microbiol. Biotechnol. 2002, 59, 143-152.

6. Riser-Roberts, E. Remediation of Petroleum Contaminated Soils: Biological, Physical, and Chemical Processes; Lewis Publishers CRC Press LLC: Boca Raton, FL, 1998, p. 542.

7. Widada, J.; Nojiri, H.; Omori, T. Appl. Microbiol. Biotechnol. 2002, 60, 4559.

8. Vogel, T.M. Curr. Opin. Biotechnol. 1996, 7, 311-316.

9. Top, E.M.; Springael, D.; Boon, N. FEMS Microbiol. Ecol. 2002, 42, 199208.

10. Berry, C.J. Masters thesis; Georgia Institute of Technology, Atlanta, GA, 2005.

11. Phillips, R.W.; Wiegel, J.; Berry, C.J.; Fliermans, C.; Peacock, A.D.; White, D.C.; Shimkets, L.J. International Journal of Systematic and Evolutionary Microbiology. 2002, 52, 933-938.

12. Anderson, A.W.; Nordan, H.C.; Cain, R.F.; Parrish, G.; Duggan, D. Food Technol. 1956, 10, 575-577.

13. Charpak, G., R. L. Garwin. Europhysics News. 2002, 33, pp 24.

14. Smith, K.P.; Arnish, J.J.; Williams, G.P.; Blunt, D.L. Environ. Sci. Technol. 2003, 37, 2060-2066. 
15. DuPont, R.R. Environ. Prog. 1993, 12, 45-53.

16. Alexander, M. Biodegradation and Bioremediation; Academic Press: San Diego, CA, 1999; Vol. 1, p. 453.

17. USEPA. Manual: Bioventing Principles and Practice; 540/R 951534a; U.S. EPA, Washington, DC; 1995.

18. Hinchee, R.E.; Downey, D.C.; Dupont, R.R.; Aggarwal, P.K.; Miller, R.N. J. Hazard. Mater. 1991, 27, 315-325.

19. Miller, R.V.; Poindexter, S. Strategies and Mechanisms for Field Research in Environmental Bioremediation; American Academy of Microbiology, Washington, DC, 1994; pp.20

20. von Wedel, R.T.; Mosquera, S.F.; Goldsmith, C.D.; Hater, G.R.; Wong, A.; Fox, T.A.; Hunt, W.T.; Paules, M.S.; Quiros, J. M.; Wiegand, J.W. Water Sci. Technol. 1988, 20, 501-503.

21. Freijer, J.I. J. Environ. Qual. 1986, 25, 296-304.

22. Dick, W.A.; Tabatabai, M.A. Use of Immobilized Enzymes for Bioremediation. in Bioremediation of Contaminated Soils; American Society of Agronomy Inc., Madison, WI, 1999; pp.315-338

23. Acosta-Martinez, V. and Tabatabai, M.A. Soil Biol. Biochem. 2001, 33, 17 23.

24. Alexander, M. Introduction to Soil Microbiology; John Wiley \& Sons: New York, 1977; Vol. 1, p. 467.

25. USEPA, Bioremediation of Hazardous Waste Sites Workshop, CERI 89-11; U.S. EPA: Washington, DC, 1989.

26. Shimp, R.J.; Pfaender, F.K. Appl. Environ. Microbiol. 1985, 49, 402-407.

27. Zhou, J.; Xia, B.; Treves, D.S.; Wu, L.-Y.; Marsh, T.L.; O’Neill, R.V.; Palumbo, A.V., Tiedje, J.M. Appl. Environ. Microbiol. 2002, 68, 326-334.

28. Borsma, T.N.P.; Middeldorp, P. J. M.; Schraa, G.; Zehnder, A. J. B. Environ. Sci. Technol. 1997, 31, 248-252.

29. Villemur, R.; Déziel, R.E.; Benachenhou, A.; Marcoux, J.; Gauthier, E.; Lépine, F.; Beaudet, R., and Comeau, Y. Biotechnol. Prog. 2000, 16, 966972.

30. Harms, H. and Bosma, T.N.P. J. Ind. Microbiol. Biotechnol. 1997, 18, 97105.

31. Thomas, J.M.; Yordy, J.R.; Amador, J.A.; Alexander, M. Appl. Environ. Microbiol. 1986, 52, 290-296.

32. Bruheim, P.; Bredholt, H.; Eimhjellen, K. Can. J. Microbiol. 1997, 43, 1722.

33. Ward, D.M.; Brock, T.D. Appl. Environ. Microbiol. 1975, 31, 764-772.

34. Hillel, D. Soil Structure and Aggregation: Introduction to Soil Physics; Academic Press: London, 1980; pp. 40- 52, 200-204.

35. Atlas, R.M. Microbiological Review. 1981, 45, 180-209. 
36. El-Nawawy, A.S.; El-Bagouri, I.H.; Abdal, M.; Khalafai, M.S. World Journal of Microbiology and Biotechnology. 1992, 8, 618-620.

37. Roane, T.M.; Josephson, K.L.; Pepper, I.L. Appl. Environ. Microbiol. 2001, 67, 3208-3215.

38. Makkar, R.S., and K. J. Rockne. Environmental Toxicology and Chemistry. 2003, 22, 2280-2292.

39. Barbeau, C.; Deschenes, L.; Karamanev, D.; Comeau, Y.; Samson, R. Appl. Environ. Microbiol. 1997, 48, 745-752.

40. Altman, D.J.; Hazen, T.C.; Tien, A.J.; Worsztynowicz, A.; Krzysztof, U. The Czechowice Oil Refinery Bioremediation Demonstration of a Process Waste Lagoon - Czechowice-Dziedzice. Poland.; WSRC RP-97-214, Westinghouse Savannah River Company: Aiken, S.C.,1997.

41. Brigmon, R.L.; Berry, C.J.; Story, S.; Altman, D.; Upchurch, R.; Whitman, W.B.; Singleton, D.; Plaza, G.; Ulfig, K. Bioremediation of Petroleum and Radiological Contaminated Soils at the Savannah River Site: Laboratory to Field Scale Applications; WSRC-MS-2004-00363, DOE: Savannah River Site, 2004.

42. USEPA. SW-846 On Line: Test Methods for Evaluating Solid Wastes Physical Chemical Methods. 2005 [cited 2005]; Available from: http://www.epa.gov/epaoswer/hazwaste/test/main.htm.

43. IARC. Diesel and Gasoline Engine Exhausts and Some Nitroarenes; International Agency for Research on Cancer: Lyon, France, 1989; Vol. 46, pp. 458.

44. Huesemann, M.H. Environ. Sci. Technol. 1995, 29, 7-18.

45. Frysinger, G.S.; Gaines, R.B.; Xu, L.; Reddy, C.M. Environ. Sci. Technol. 2003, 37, 1653-1662.

46. Prince, R.C.; Grossman, M.J. Appl. Environ. Microbiol. 2003, 69, 58335838.

47. Leson, G.; Winer, A.M. Journal of the Air and Waste Management Association. 1991, 41, 1045-1054. 